\title{
Governance and administrative process of the Light Rail Train project in Palembang, Indonesia
}

\section{Light Rail Train project in Palembang, Indonesia}

\author{
Muhammad Akbar Hairi \\ Huazhong Science and Technology University
}

\begin{abstract}
Purpose - The paper investigates the governance and administrative process in the Palembang Light Rail Train (LRT) project in Indonesia and gives suggestions on the strategic development of the LRT project for creating a desakota technopole in Palembang.

Design/methodology/approach - This paper adopts both STEEP (Social, Technological, Environmental, Economic, Political) analysis and desakota technopole theoretical framework. The STEEP analysis is used to explain the Palembang LRT project which is to meet one of the city's high-tech urban transportation goals. The desakota technopole framework is used as a strategic urban planning guideline for the further development of Palembang.

Findings - This paper has three findings. First, based on STEEP analysis, Palembang needs smart urban transportation, such as LRT, to solve the present and future traffic problems. Second, the governance and administrative process in the LRT project is mandated to national companies as part of a national government infrastructure policy financed over multiple years through the national budget. Third, it is critical for national, provincial, and local governments to adopt a desakota technopole framework strategy to meet long-term targets.
\end{abstract}

Originality/value - This paper highlights Indonesia experience towards making a desakota technopole, using the Palembang LRT project policy as the key driver under investigation.

Keywords Palembang LRT project, Governance, Administrative process, Desakota Technopole, Indonesia Paper type Research paper

\section{Introduction}

Making a proper city is a kind of art, based on strong principles that go far beyond conventional formulae for architecture, engineering, and land-use planning (Landry, 2006). Accordingly, Palembang in Indonesia has to embrace its cultural uniqueness and its combined desa (village) and Kota (city) (also called "desakota") characteristics (McGee, 1991) to facilitate its becoming a more creative city (Scott, 2006). The very definition of "smart" is evolving to include full integration of transport, electricity, healthcare, education, city services, water-heating, work, and leisure activities, coordinated through the Internet of Things (IoT) framework, which brings the crucial elements of life together into a single, unified picture (Mcclelland, 2015). Previous research and academic publications related to Palembang discourses are used as a foundation for this paper.

To balance the goals of becoming a smart city and preserving local cultural uniqueness requires not only "art and design" traditions, but also a knowledge system and innovative approach to management and technology that stresses empathy (Ip and Yip, 2017). Palembang is widely regarded as one of Indonesia's most rapidly growing cities (Vivanews,

(C) Muhammad Akbar Hairi. Published in Public Administration and Policy. Published by Emerald Publishing Limited. This article is published under the Creative Commons Attribution (CC BY 4.0) license. Anyone may reproduce, distribute, translate and create derivative works of this article (for both commercial and non-commercial purposes), subject to full attribution to the original publication and authors. The full terms of this license may be seen at http://creativecommons.org/licences/by/4.0/ legalcode

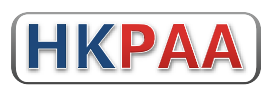


2018) and is identified as one of 100 planned new smart cities in Indonesia's national policy agenda (Kominfo, 2017).

Local government policy requires that Palembang's cultural heritage be supported (Prima, 2014) to improve tourism and benefit the town's economic development (Lussetyowati, 2015). At the same time, domestic infrastructure investments are being made to make Palembang more accessible and facilitate visions for its future (Podlaszewska, 2017). The Palembang LRT project is a matter of both public governance and investment to improve accessibility to Palembang. It is relevant and attractive as a subject study in the public administration field, particularly in the context of governance and administrative processes related to the Palembang LRT project.

Palembang has to embrace more strategic and innovative ways of maximizing the longterm benefits of not only the Palembang LRT, but also ongoing desakota technopole development. Therefore, the following research questions (RQs) are pursued:

RQ1: What are the unique development characteristics of Palembang regarding creating a desakota technopole?

RQ 2: What are the governance and administrative process problems in the Palembang LRT project and what should Palembang Municipality do to improve and maximize the LRT's contribution to the city's desakota technopole development?

This paper starts by discussing the unique development characteristics of Palembang towards a desakota technopole (RQ 1). This paper is a case study, using desakota technopole theory as its framework, supported by interviews and document analysis. In addition, the governance and administrative processes of the Palembang LRT project, how national infrastructure policy acts as a key driver, who are the key policy actors, and the results of the Palembang project are discussed (RQ 2). The desakota technopole framework strategy is used to maximize the Palembang LRT's benefit to the city and avoid its becoming a "white elephant" (RQ 2). The paper ends with a summary, in which the findings and positive and negative results of the Palembang LRT project are reviewed.

\section{Unique development characteristics of Palembang towards Desakota Technopole}

Palembang is the capital city of South Sumatera Province in Indonesia. Since 1998, as the beginning of Indonesia's political reform era, Palembang has had a significant decrease in criminal activity (Sripoku, 2019). Its development activity is split between the old town (near the Musi and Ampera bridge) and the new town (a commercial area in north-eastern and north-western Palembang). The LRT is a part of high-tech urban transportation scheme to connect and improve accessibility to both towns, following the examples set by Singapore's LRT, Tokyo's MRT, and Shanghai's MRT.

Modern lifestyles have influenced Palembang citizens through rapid development and greater demand for higher education, as shown by the construction of a new private academy, higher education institutes, and universities at the centre of the town. Commercial areas began to spring up in Palembang when the city hosted several international events in the 2010s. Five modern malls - Palembang Trade Centre, Palembang Square, Palembang Icon, Palembang Trans Mart, and OPI Mall - highlight the variations in business infrastructure development in Palembang's new town. The new town has attracted foreign investment to Palembang, including four- and five-star business hotels, such as Novotel Hotel, Excelton Hotel, Aston Hotel, Ibis Hotel, Arista Hotel, Windham Opi Hotel, and Hotel Santika Bandara Palembang. The following three figures (Figure 1-3) describe Palembang's tourism, land use development, and desakota characteristics: 


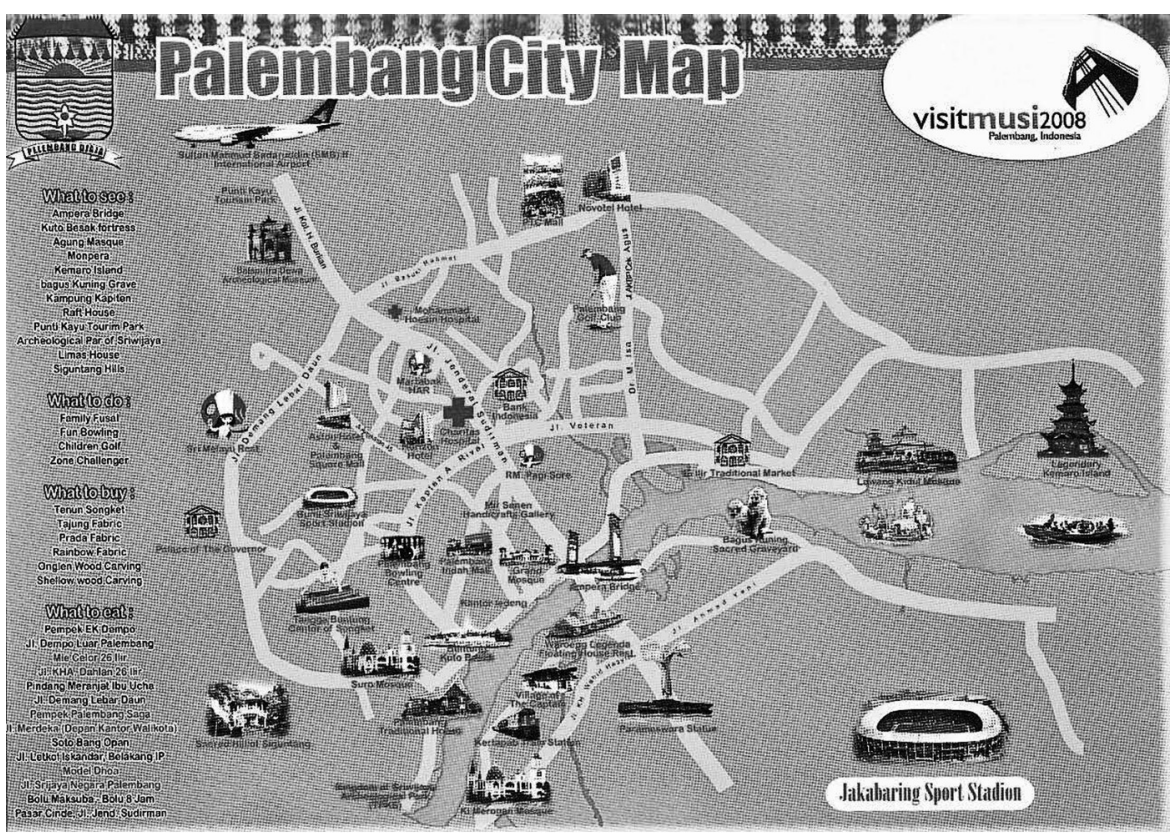

Light Rail
Train project in
Palembang,
Indonesia
$\mathbf{3 0 1}$

Source: Adapted from Visitmusi2008 (2007)

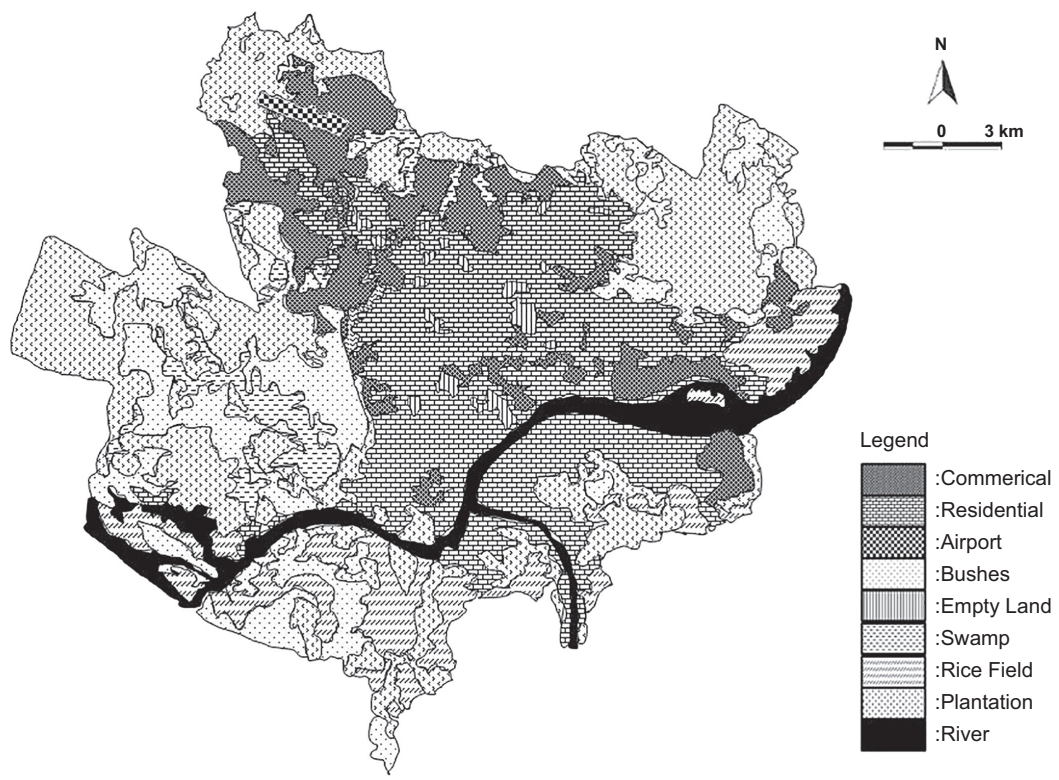

Figure 2.

The development land usage map in

Source: Adapted from Podlaszewska (2017)

Palembang city 2010 


\section{PAP}

23,3

\section{2}

Figure 3.

Desakota

characteristic map of

Palembang city with

Palembang LRT lines

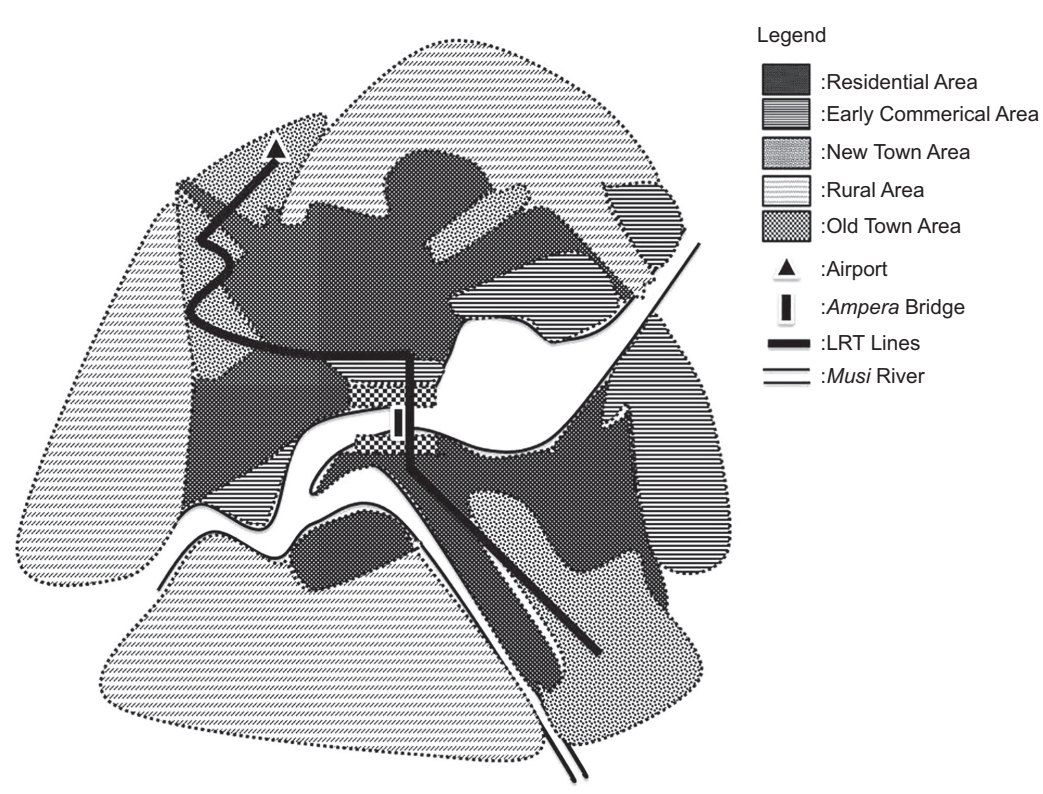

Source: By author (2019)

Verma et al. (2019) offered a salient discussion of Palembang, using STEEP (i.e., Social, Technological, Environmental, Economic, Political) analysis. STEEP analysis offers a better understanding of Palembang's current achievement and conditions, from a systematic perspective.

First, the social aspect relates to the population composition, cultural values, and literacy of Palembang citizens. In 2018, the total population of Palembang was 1.6 million, with a population growth rate of 1.42 percent per year. According to a 2009 official national socialeconomic survey (BPS Indonesia, 2019), over half of all Palembang citizens had obtained a high school diploma or higher education degree and had Internet access, more than 80 percent used smartphones and sophisticated gadgets, and almost 100 percent were literate. Palembang's human development index reached 69.39 points in 2019 (BPS Kota Palembang, 2019). Furthering human resources development is becoming a priority and a key part of national efforts to improve education, vocational ability, training quality, and other skills (Aggarwal, 2019). At the same time, however, those living in old town areas must still preserve heritage sites, such as their traditional houses (Prima, 2014). Finally, religion greatly influences Palembang citizens' lifestyles and traditions. According to a Department of Religion report (Kemenag Sumsel, 2016), Palembang citizens embrace a range of religious beliefs, with 91.9 percent being Muslim, 4.52 percent Christian, 3.46 percent Buddhist, and 0.08 percent Hindu.

Second, from a technological perspective, Palembang is not considered a high-tech city, in terms of productivity. Most industries in Palembang - e.g., electric power generation and distribution, water utilities, food producers, transportation, and clothing - use low- to midlevel technology in their daily operations. A national electricity company, PLN (Pembangkit Listrik Negara) oversees electrical power generation in Palembang, using such nonrenewable fuels as petroleum and liquid petroleum gas (LPG) (Interview Head Manager of Palembang PLN). Technology in the water utility is still below modern city standard, with water quality and quantity depending greatly on the climate and topography of the 
residential area. In terms of public transportation technology, Palembang has a railway station with a medium-technology, medium-speed train, while city buses run on LPG. The most famous industry in Palembang with national scale production is PT Pusri, which produces urea fertilizer for agricultural uses. However, the food, clothing, and local handcraft industries follow the home-industry model, with all its inherent productivity limitations.

Third, in terms of environment, Palembang has had, since its early days, unique development characteristics. The Musi River has been the main driver of Palembang's development since the Majapahit kingdom era, leading to the city being regarded as 'the Venice of the East' in the $11^{\text {th }}$ century (Podlaszewska, 2017). The river not only provides Palembang with river access to the outside world, it also supplies primary life consumption resources for its native people, such as fishes, water, and vegetables. The river divides Palembang's old town into two major areas (Figure 2) with two distinct cultural identities and vernacular architecture - the iliran (Palembang's northeast region) and uluan areas (Palembang's southwest area) (Podlaszewska, 2017). The earliest and flagship development in Palembang's commercial area (Figure 3) was near the iliran and uluan areas of Palembang (Podlaszewska, 2017). The Ampera bridge, a Palembang icon, is also beside the river.

The old town area is the city's main source of domestic and international tourism. Its many heritage sites, public spaces for urban mega-events, native residential areas, local restaurants, and trading and economic activities affect the development of other areas of the city (Podlaszewska, 2017). As such, the area was rebuilt and reconstructed by the local municipality to include green, open spaces and tourist vistas representative of Palembang. Part of this reconstruction involved increasing urban mobility, both for improved resident access and visitors' convenience.

Palembang's 40,062 square kilometers area has a low-lying topography, which causes large puddles during the rainy season, with most of the unspoiled rural area near the Musi River becoming a swamp at the rainy season's peak (BPS Kota Palembang, 2019). Some flat areas located near the river or swamp are used for agricultural purposes, including growing rice, sweet potatoes, and peanuts (BPS Kota Palembang, 2018).

Fourth, from an economic perspective, the purchasing power of Palembang's citizens has increased significantly, with economic growth reaching 6.69 percent in 2018, and only 10.95 percent of its citizens being considered poor (BPS Kota Palembang, 2018). Palembang citizens' day-to-day consumption averages \pm 100 US $\$$ per month, among which 35.77 percent is used for drink and food and 11.61 percent for cigarettes (BPS Kota Palembang, 2019). In 2018 , the labour participation rate was 60.71 percent; the labour opportunity rate was 92.79 percent; the part-time job rate was 35.86 percent; and the unemployment rate was 7.21 percent. Most urban workers in Palembang were in service, trade, wholesale/retail, food processing, manufacturing, conventions, or primary functions, such as water treatment and waste disposal; others were in the transportation, warehousing, and communication sectors. China has become a top-ranked export and import trading partner of south of Sumatera Province, especially under the President Jokowi regime (BPS Kota Palembang, 2018).

Finally, in terms of politics, although most Palembang citizens are Muslim, the five topranked political parties in the local assembly are nationalist or non-Islamic in nature (BPS Kota Palembang, 2019). The political system includes checks and balances between the municipality and the local assembly. The two bodies coordinate and evaluate city progress annually in such areas as tax revenue, investments, and city budgeting.

Based on the above STEEP analysis of Palembang, the environmental aspect is the dominant force in forming desakota development. The old town's support for tourism development makes it the city's flagship development area, which in turn further fosters its tourism. This triggers other areas to develop more rapidly in social, economic, and technological aspects. Accordingly, infrastructure development aims to facilitate and connect the old town area of Palembang, with the Palembang LRT project connecting the new and old 
PAP

23,3

304

town areas being a "piece of the puzzle" to create a desakota technopole. The political aspect (local government) provides policy direction and support for the environmental aspect (continuing the development of the old town area) (Prima, 2014).

High-tech investment in other industries will further benefit Palembang. For example, the high-tech processing industry will benefit from increased quality in such service areas as water, electricity, waste disposal, and food production and processing. High-tech communication technologies will not only contribute to such sectors as the culinary industry - a core element of Palembang's tourism - allowing it to recruit more employees and absorb more of the city's low-income, low-educated men and women into the job market (Wang et al., 2019; Saner and Yiu, 2019), but also foster the city's information, visualization, and propaganda efforts. Similarly, switching from its current non-renewable sources of energy to green technologies, such as solar or hydro-electric energy systems, will benefit Palembang by improving its air quality. Moreover, Palembang should also consider improving other aspects, such as supporting local art inclusion (Cheung et al., 2019).

\section{The Desakota Technopole theoretical framework on the smart city context}

Cities have to adopt new technical innovations to review existing systems or challenge the present situation in order to be more cohesive cities (Gerometta et al., 2005). A crucial problem facing the city is traffic (Bulu, 2014), making the introduction of new supports for effective and efficient public transport - including interconnected, convenient facilities - a priority (Bibri, 2018).

Integrating smart transportation systems improves cities' operational efficiency by optimizing the time, cost, reliability, and safety elements of urban transportation (Bhagya et al., 2018). Smart mobility is one of six pillars of the smart city (Giffinger et al., 2007). Giffinger and colleagues defined smart mobility as physical capability supported by ICT infrastructures; it should be sustainable and innovative, with secure data transportation and feature local, national, and international network connections.

The LRT project is part of Palembang's new smart transportation infrastructure and one of its initiatives to ensure efficient transportation in the future. According to Castells and Hall's (1994) technopole framework, McGee's (1991) desakota framework, and Seitinger (2004), the desakota technopole can be the foundation of emerging cities' rural-urban transformation, social and economic development efforts, and urban high-tech transportation development initiatives. They describe the concept, its range, and its aims as follows:

Depending on its orthography, technopole indicates an independent urban entity or a centre of attraction (a pole or node) within the broader urban context when spelling technopole (Castells and Hall, 1994, p.1).

Relevant within technopole framework, desakota areas are described as outside the periurban zones, sprawl alongside arterial and communication roads, and characterized by high population density and more urban than rural characteristics (McGee, 1991, pp. 6-7).

The range of technopoles meaning reflects the diversity of projects, which not only resembles megaprojects and urban development schemes, but also includes specific characteristics to make them high-tech business environments and live-work areas (Seitinger, 2004, p. 18).

Technopoles attempt to plan and promote the concentration on technologically innovative and industrial-related production, like technology parks, science cities, technopoles, and so forth (Castells and Hall, 1994, p. 8).

Thus, a technopole conceptualizes an independent urban identity that depends on the city's orthography. Technopole concepts do not focus on specific schemes for projects, megaprojects, or urban development; rather, they build on existing city characteristics to create 
high-tech business environments and live-work areas. Technopoles aim to promote innovation, industrialized productivity, technology parks, or science cities.

Furthermore, technopoles require continuous investment to synergize production through social, institutional, organizational, economic, and territorial structures and create new jobs and new industries to cross-fertilize business formation. However, though entrepreneurship is a vital component, a technopole should not focus on fostering economic competition alone and abandon human imagination (Castells and Hall, 1994).

Technopoles reach their full potential by developing a skilled labour force and abundant supplies of capital for private, public, and non-profit entrepreneurs' business activities (Seitinger, 2004). Internet Communication Technology (ICT) infrastructure and specialized research encourage project developers to implement new ideas and become more innovative (Castells and Hall, 1994). Innovation comes from both scientific and artistic knowledge that can be commercialized for added value. Seitinger (2004) emphasized the technology requirement in technopoles, saying:

The most effective way to promote better urban spaces with the help of technology is to emphasize the reciprocal relationship between user and developer with specific technologies over time and to adjust the measures to different conditions in terms of present situation and experimentation (Seitinger, 2004, p. 57).

To support economic development, cities should approach technology through careful design, taking advantage of technologies and their special functions and uses (Castells, 2001). Technopoles create high-technology information products, but are themselves born out of the high-technology information process that comprises the mines and foundries of the information age (Castells and Hall, 1994). Although there are similarities and differences in the economic situations of developed and developing countries, the spread of ICT has proven advantageous for implementing low-cost, high-value planning and design strategies, which particularly benefit developing countries. A country that successfully implements a technopole is not only rewarded with greater economic growth and better quality life of its citizens, it also acquires more cultural and political influence, increasing its soft power relative to other countries (Mitchell et al., 2001).

\section{Research methodology}

This paper is based on a STEEP analysis of Palembang's unique characteristics. STEEP analysis provides a snapshot of the city's progress in, potential for, and essential needs regarding Desakota Technopole. From a technology perspective, one of Palembang's requirements is smart transportation technology to form new modes of urban transportation. The technopoles framework will provide new knowledge systems to spur the city's further economic development.

It is essential to understand the city's governance, administrative process, and related details. The synergy and investments created by the LRT project will spur innovation and enhance economic development. Additionally, the project will generate short-term revenue for the city by attracting other investors, both local and foreign. A case study of Palembang is critical for providing the empirical evidence necessary for a developing country like Indonesia.

This paper is a case study that uses document analysis and interviews as its research foundation (Yin, 2013). It begins with a literature review of relevant international journal articles, academic and other publications in the government official statistics in BPS Kota Palembang (online and offline) and the national and international press. Based on the literature review and document analysis, the author identifies the significant relations between the Palembang LRT project and the desakota technopole framework, in the context of Palembang. The author also highlights information from key interviewees, especially local 
PAP

23,3

public figures and municipal managers, to enrich the desktop analysis. A list of the interviewees and interview outline are presented as below:

\section{Governance and administration in Palembang LRT project}

The beginning of the Palembang LRT project: context and key drivers

The Palembang LRT project began on 20 October 2015 as authorized by President Jokowi. Under the terms of the LRT project approval, the central government contributed approximately 10.2 trillion rupiahs $( \pm \mathrm{US} \$ 755$ billion) in financial support. This project was carried out by two state-owned companies - PT Waskita Karya to handle the LRT infrastructure, and PT INKA to manufacture the LRT components - both of which were financially supported through the Ministry of Finance's budget (Setkab, 2018; Suara, 2017).

Palembang was selected to host the 2018 Asian Games, having previously gained worldwide reputation for successfully hosting significant national and international events. According to Governor Alex Noerdin of South Sumatera (Indopos, 2018), there were three reasons underlying the decision.

First, South Sumatera Province (Palembang), has never experienced any ethnical or religious conflicts, which showed that the region is conducive. Second, Palembang has already been tested as host in PON 2014 (National Sports Events), Sea Games 2011, Islamic Solidarity Games 2013, ASEAN University Games 2014, Asian Triathlon Championship 2017 and many other events on a national and international scale. Third, it has the sport facilities that are fully integrated into one place. All athletes only need to walk 1-10 minutes from the dormitory to the arena for access. Besides, in 2017, Jakabaring Sports Centre has already acquired a certificate of class two facilities from the International Association of Athletics Federations.

The initial plan for the Palembang LRT project was to build a connection linking the Palembang airport to Jakabaring Sports Center, so the latter could serve as the main venue for the 2018 Asian Games. Palembang LRT project includes 13 stations over a total length of 23.4 kilometres, with some stations being connected to unique Palembang sites, such as Palembang Icon (new town), Masjid Agung, and Ampera bridge (old town area). The project's short-term purpose was to carry all Asian Games athletes from the airport to the sports centre, without causing traffic problems in downtown Palembang.

\section{Palembang LRT project as part of National Strategic Project}

The Republic of Indonesia and the People's Republic of China first began bilateral economic discussions in 1993. The two countries' movements towards cooperation intensified in the 2000s, after China arguably became one of the world's leading economic powers. Although economic cooperation between China and Indonesia was first discussed in 2001, China did not officially cement its investments until 2015, after a bilateral conversation between President

Table 1.

\section{Interviewees}

Role

Occupation

\section{A}

Types of interviewees

Municipality

Local Politician

Company Manager
Mayor of the City Head of Local Assembly Local PLN
Table 2 . Interview outline

\footnotetext{
A personal view about the present problems, the city potential, and future challenges of the city. Palembang LRT project in the context of city planning and local municipality's concern.
} 
Xi Jinping and President Jokowi at the Asia-Africa Conference in Bandung (Kompas, 2015). At the conference, the two nations reached a formal agreement that specified every aspect of infrastructure policy needed to implement the cooperation smoothly.

In 2014, Indonesia's national government had formed a Committee for the Acceleration of Priority Infrastructure Development (KPPIP) which coordinates six ministries to enhance various national strategic projects (under the master plan of PSN). China's government also introduced the China International Contractors Association (CHINCA), an infrastructure contracting organization that would be involved in and contribute to investment in Indonesia's PSN (Media Indonesia, 2019) as part of the Regional Comprehensive Economic Corridor (RCEC) and the Global Maritime Fulcrum-Belt and Road Initiative between Indonesia and China. It also indicated that CHINCA members would become consultants for KPPIP (Media Indonesia, 2019).

The Palembang LRT project and Jakarta-Bandung High-Speed Rail (HSR) have different situations and processes in the PSN project. Specifically, the HSR project followed the China National Company's and the Indonesia National Company's Business to Business (B2B) scheme (Kementerian Keuangan Indonesia, 2016). The project began with PT Pilar Sinergi BUMN Indonesia (an Indonesian national company), which later formalized a Joint Venture Agreement with China Railway International Co. Ltd (a Chinese state enterprise); eventually, the two established a consortium, called PT Kereta Cepat Indonesia China.

In contrast, the Palembang LRT project was perceived as part of national infrastructure policy, with PT Waskita Karya (a national company) authorized to complete the project. Furthermore, according to Sri Mulyani (Minister of Finance in President Jokowi's cabinet), the budget for the Palembang LRT project was provided by the national budget (APBN), due to the urgency of having the project operating in time for the 2018 Asian Games (Suara, 2017). After the project's cost and a payment mechanism were agreed upon by the contractor, the Ministry of Transportation, and the Ministry of Finance, the Palembang LRT project was carried out by PT Waskita Karya and PT INKA, with the help of KPPIP consultants.

Chinese capital and business developers have played critical roles in Indonesian infrastructure projects under Jokowi's regime, including the Palembang LRT project. For example, as leader of the Palembang LRT project, PT Waskita Karya received financial support from the Guangxi Road and Bridge Engineering Group (GRBG) to complete the project (Warta Ekonomi, 2019). Under the terms of its formal agreement with KPPIP, PT Waskita Karya invested in Palembang LRT project using its own company funds, first; then, the Indonesian government reimbursed it, plus the investment interest, using the national APBN's multi-year program. After the project's completion, the daily operation of the Palembang LRT was managed by a local company, BPKAR Sumsel. All income from Palembang LRT tickets is transferred to KPPIP, which assumes all maintenance costs (Kementerian PPN/Bappenas, 2015) (Figure 4).

China played a key role in Indonesia's national infrastructure policy under President Jokowi in order to realize its Belt and Road Initiative. Among ASEAN countries, Indonesia received the greatest proportion of China's infrastructure investments (Tempo, 2019). Investment in transportation technology was one of the prime targets involving developers and contractors from China, who had experience in extensive mass transit projects. The Palembang LRT project adopted the "Build, Operate, and Transfer (BOT)" contract scheme, a transportation planning and development plan in which the "process" remains in the hands of the contractor/builder until all work has been completed, to minimize risks. However, as the Palembang LRT project was mainly financed thought the national APBN budget and there was a chance Jokowi would not win the 2019 Presidential election, Indonesia's political stability was a major concern for foreign investors (Aggarwal, 2019). Jokowi did win, however, retaining the presidency until 2024, reducing the anxiety of Chinese investors and ensuring infrastructure projects with China would continue under Jokowi's national infrastructure policy. 


\section{PAP}

23,3

308

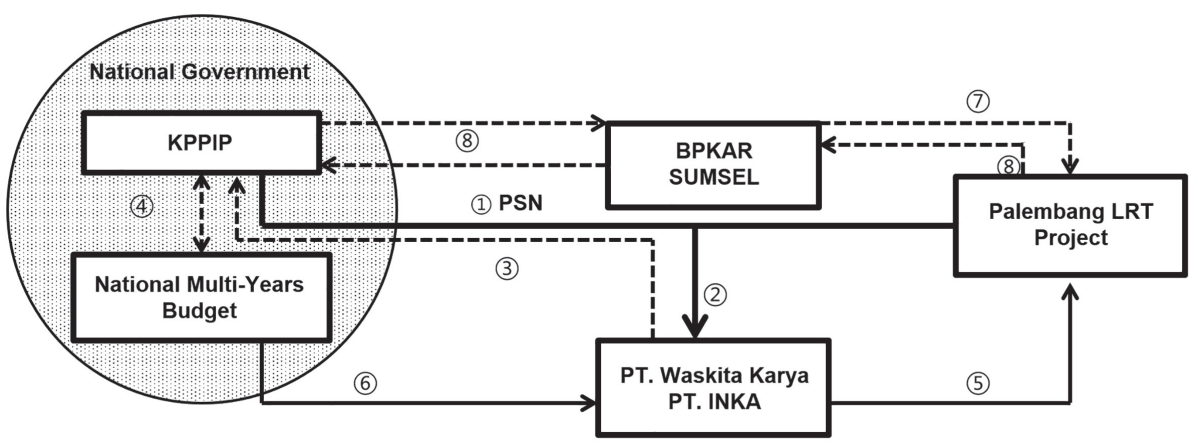

Notes:

(1) KPPIP, based on Peraturan Presiden No. 116 Tahun 2015, executed a PSN (Palembang LRT project) for the 2018 Asian Games.

(2) KPPIP gave a mandate to PT Waskita Karya and PT INKA to develop the project.

(3) PT Waskita Karya and project consultants accepted the mandate and proposed a budget for the Palembang LRT project to KPPIP.

(4) KPPIP consulted with the Ministry of Finance and agreed to invest in the Palembang LRT project, using its national multi-year budget. However, the Ministry of Finance requested $P T$ Waskita Karya use its company budget to develop the plan until the project had been completed. The national government agreed to pay the project costs, plus interest, from the national budget every year.

(5) PT Waskita Karya and PT INKA began to develop the Palembang LRT and met the project deadline.

(6) Ministry of Finance started to repay PT Waskita Karya's debt and interest, including 350 billion rupiahs in 2016; 1.7 trillion rupiahs in 2017, and 4 trillion rupiahs in 2018; the total cost of 10.9 trillion rupiahs is to be paid off by 2020 .

Figure 4.

Governance and administrative process on Palembang LRT project
(7) After Palembang LRT began operating, a local company (BPKAR Sumsel) took over its daily operation.

(8) BPKAR Sumsel collects LRT tickets revenue and transfers it to KPPIP. In turn, KPPIP is responsible for maintenance of the Palembang LRT. Any revenue surplus becomes national revenue.

Source: By author (2019)

\section{Develop Technopole framework strategy in Palembang LRT project to avoid "Big White Elephant" phenomenon}

According to the technopole theoretical framework, it was salient for policymakers to apply creative and clear strategies to maximize the Palembang LRT benefit. First, policymakers understood the Palembang LRT's short-term goal and reviewed the obstacles to the project. The project successfully met its short-term aim, which was to transport athletes from Palembang airport to and from the 2018 Asian Games venue. However, various obstacles and shortcomings appeared after the Games, including insufficient passengers (Liputan6, 2019) and technical operation problems (Kompas, 2018), that had to be reviewed to realize the Palembang LRT project's long-term strategy.

Second, policymakers and LRT management considered creative solutions to the problem of insufficient passengers, such as giving fare discounts for special events (e.g., national and local holidays) and particular passengers (students, teachers, civil servants, loyal customers). 
This strategy aimed to develop a sense of belonging among citizens and encourage them to view the LRT as a city utility trademark. LRT developers were expected to cope with technical operation problems by themselves; however, it was deemed essential that they inform the local municipality of the source of those problems. Furthermore, the national government and national companies were expected to build a synergistic relationship with local institutions with entrepreneurial capacities - such as municipalities, local political leadership, and universities - to facilitate further creative and innovative approaches to LRT operations.

As mentioned earlier, there is an urgent need to build a reciprocal relationship between users and developers to create an experimental environment that will benefit both (Seitinger, 2004). KPPIP, as an authorized operator of the LRT, should involve Palembang municipality in further long-term strategies for its operation, as local districts can better understand the specific characteristic of the city. More importantly, without political support from local municipalities, the Palembang LRT will not work efficiently to increase the city's productivity and revenue. The daily operation of the Palembang LRT is under the provincial government (BPKAR Sumsel). The national government should avoid political storms and learn from the experiences of other cities that have suffered from conflicts between the local and the national governments due to a lack of sensitivity (Tsang, 2019) and political dissatisfaction (Cheung, 2019). In their interviews, Palembang's mayor and the head of the Local Assembly expressed their concerns and identified certain discrepancies:

To measure whether the Palembang LRT project is successful requires at least five years of operation after the project is done. One problem is that the Palembang LRT is not linked to other Palembang transportation modes yet. Indeed, the Palembang LRT is perceived as the political product of Alex Noerdin (the previous South Sumatera Governor), not Herman Deru (the present South Sumatera Governor). This influences the debate in the governor's office over whether to continue the project or not. Our local budget is only sufficient to subsidize Trans-Musi (not the Palembang LRT) (Municipality-Interviewee A).

We have already discussed with the Ministry of National Transportation the short- and middle-term plans for the Palembang LRT. We told them, "Please place Palembang LRT under Palembang municipal control, if it has not been agreed how long the Ministry will subsidize Palembang LRT tickets." This is because we cannot cover all the maintenance costs of Palembang LRT and the local budget has been subsidizing Trans-Musi. I think the Ministry of National Transportation should talk with the mayor of Palembang to find win-win solutions. If it has been agreed, allow Palembang municipality to use space in Palembang LRT stations for advertisement revenue. The national government should understand, if the mayor fails to maximize the benefit of Palembang LRT, it will affect local assembly performance and credibility. Both parties need each other's political support to support the further development of Palembang (Local Politician-Interviewee B).

However, according to Kementerian PPN/Bappenas (2015), Palembang LRT will remain under national government supervision until at least 2020, until all project costs have been paid off by the annual national budget. The national government should use Palembang LRT's profits to support national revenue and decrease its reliance on loans from China. Jakabaring Sports Center, as an icon of Palembang's new town area, has to maintain its history of excellence when hosting national or international events to help foster spectator loyalty and give a feeling of spectacle to competing athletes. Students at nearby universities or schools can also be developed into loyal spectators.

Long-term planning for Palembang LRT should align with the STEEP analysis of city characteristics. For example, the city's culinary outlets are a tourist destination and leading source of revenue and local economic activities, as one local politician explained:

Palembang is not a city with beaches and not a tourism city; our profile is food and service. Our local government revenue comes from food tax and service. That is why our mayor pushes to open new

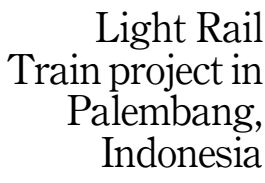

309 
PAP

23,3

310

restaurants, hotels, and pedestrian districts, to increase local government revenue. Because Palembang does not have any scenic spots, we focus on our entertainment industry; that is why we build so many entertainment venues, such as hotels, cinemas, and discotheques (Local PoliticianInterviewee B).

Previous data show that more than 80 percent of Palembang citizens use smart communication technology/gadgets (BPS Kota Palembang, 2018). Local government also uses social media as information and communication tools for customers and sellers, as most Palembang citizens are familiar with sophisticated gadgets.

To further Palembang's economic development, the national government should consider emulating China's experience with Alipay and WeChat to build connectivity between customers and sellers and boost economic development in the culinary sector. Future development of the Palembang LRT line should include new routes that connect other places, especially in the western part of the city. If Palembang LRT does not embrace a development vision that reflects a STEEP analysis of Palembang's unique desakota technopole characteristics, it risks becoming a "white elephant" - a possession that is not wanted by its owner but is difficult to dispose of, or whose expense is out of proportion to its usefulness or value.

\section{Conclusion}

This paper discusses Palembang's uniqueness desakota characteristics, based on STEEP analysis and the desakota technopole theoretical framework. It has found there is urgent need for the government to support tourism in Palembang's old town area, while the new town area continues to develop. As shown in Figure 3, Palembang LRT connects the business areas in the city's new town and old town areas to spur productivity and economic development. To understand the Palembang LRT, as smart urban transportation, it is useful to investigate the key drivers of and administrative governance processes for the project from a localexperience perspective. In smart cities, it is critical to study governance public policy from the perspective of different countries (such as Indonesia's) implementation experiences (Pratama and Imawan, 2019).

Three lessons have been learnt. First, the Palembang LRT project connects the city's new town and old town areas, based on desakota characteristics and STEEP analysis, as a part of its urban mobility development strategy. Second, the Palembang LRT project is also a part of the national infrastructure policy (PSN) instituted under President Jokowi's regime, which provided financial support due to its urgent need to have the LRT functioning in time for the 2018 Asian Games. Third, after successful operation during the Games, Palembang LRT should be further used and developed, such as connecting the western part of Palembang (another new town). The national government should join the local municipality in creating innovative development, adopt strategies and solutions to solve technical problems.

This paper proposes that China should continue its technological and financial supports for and contributions to infrastructure development under the Belt and Road Initiative in ASEAN countries. However, the risk of political instability is becoming a primary concern of Chinese investors and this may lead to the hindrance of Chinese infrastructure investments in Indonesia. National and local governments should collaborate and maintain political stability for the sake of not only Palembang LRT, but also other projects in Palembang. This also reflects the technopole theoretical framework, which suggests reciprocal relationship between users and developers in urban high-tech advancement schemes. If the desakota technopole framework is not followed, it is possible that the Palembang LRT will become a "white elephant".

\section{References}

Aggarwal, N. (2019), "Foreign investors flock to Indonesia", Business Times, 29 August, available at: https://www.businesstimes.com.sg/hub/indonesia-74th-independence-day/foreign-investorsflock-to-indonesia (accessed 15 January 2020). 
Bhagya, N., Murad, K. and Kijun, H. (2018), "Towards sustainable smart cities: a review of trends, architectures, components, and open challenges in smart cities", Sustainable Cities and Society, Vol. 38, pp. 697-713.

Bibri, S.E. (2018), Smart Sustainable Cities of the Future: The Untapped Potential of Big Data Analytics and Context-Aware Computing for Advancing Sustainability, Springer, Switzerland.

BPS Indonesia (2019), Statistik Kesejahteraan Rakyat (Statistic of Citizens' Living Standard), Catalog 4101002 No. 04210.1913.

BPS Kota Palembang (2018), Kota Palembang Dalam Angka (Palembang City shown in numbers), Catalog 1102001.1671 No. 16710.1804.

BPS Kota Palembang (2019), Kota Palembang Dalam Angka (Palembang City shown in numbers), Catalog 1102001.1671 No. 16710.1901.

Bulu, M. (2014), "Upgrading a city via technology”, Technological Forecasting and Social Change, Vol. 89, pp. 63-67.

Castells, M. (2001), The Internet Galaxy Reflections on the Internet, Business, and Society, Oxford University Press, Oxford.

Castells, M. and Hall, P. (1994), Technopole of the World: The Making of Twenty-first-century Industrial Complexes, Routledge, London.

Cheung, A.B.L. (2019), "What has gone wrong in Hong Kong?", Public Administration and Policy: An Asia-Pacific Journal, Vol. 22 No. 2, pp. 93-96.

Cheung, A., Yu, C., Li, Q. and So, H. (2019), "An international review of arts inclusion policies: lessons for Hong Kong”, Public Administration and Policy: An Asia-Pacific Journal, Vol. 22 No. 2, pp. 173-191.

Gerometta, J., Haussermann, H. and Longo, G. (2005), "Social innovation and civil society in urban governance: strategies for an inclusive city”, Urban Studies, Vol. 42 No. 11, pp. 2007-2021.

Giffinger, R., Fertner, C., Kramar, H., Kalasek, R., Pichler-Milanovic, N. and Meijers, E. (2007), Smart Cities - Ranking of Medium-sized European Cities, Vienna University of Technology, Austria.

Indopos (2018), "Tiga Alasan Sumsel Jadi Tuan Rumah Asian Games 2018" (Three reasons why South Sumatera Province is selected as a host city of Asian Games 2018), 5 May, available at: https:// indopos.co.id/read/2018/05/05/136989/tiga-alasan-sumsel-jadi-tuan-rumah-asian-games-2018/ (accessed 15 January 2019).

Ip, A.K.C. and Yip, T. (2017), "Hong Kong's East Lantau Smart City: some innovative development concepts”, Public Administration and Policy: An Asia-Pacific Journal, Vol. 20 No. 1, pp. 39-59.

Kemenag Sumsel (2016), "Data Pemeluk Agama 2016” (Data of adherents of religion 2016), 6 Oct, available at: https:/sumsel.kemenag.go.id/artikel/view/39692/data-pemeluk-agama-2016 (accessed 15 January 2019).

Kementerian Keuangan Indonesia (2016), Menghadapi Tantangan Ekonomi 2016 (The economic challenges in 2016), Ministry of Finance, Vol. XI No. 101, pp. 14-15.

Kementerian PPN/Bappenas (2015), "Draft final business case / Draft Kajian Akhir Prastudi Kelayakan Report”, available at: https:/www.bappenas.go.id/files/pkps/monorail_palembang/ Draft $\% 20$ Kajian \%20Akhir\%20Prastudi \%20Kelayakan \%20(Final \%20Business \%20Case).pdf (accessed 15 January 2019).

Kominfo (2017), "Langkah Menuju '100 Smart City"' (Move towards 100 Smart City), 28 November, available at: https://kominfo.go.id/content/detail/11656/langkah-menuju-100-smart-city/0/ sorotan_media (accessed 15 January 2019).

Kompas (2015), "Tiongkok Sapu Bersih Proyek Infrastruktur Indonesia" (China takes charge of all the Indonesian infrastructure projects), 25 April, available at: https://money.kompas.com/read/2015/ 04/25/165045026/Tiongkok.Sapu.Bersih.Proyek.Infrastruktur.Indonesia (accessed 15 January 2019).

Kompas (2018), "PT KAI: LRT Palembang Tidak Mogok, Tetapi Gangguan Sinyal”, (Indonesian Train Company: LRT in Palembang stopped running, due to technical issue), 10 August, available at: https://regional.kompas.com/read/2018/08/10/16443261/pt-kai-lrt-palembang-tidak-mogoktetapi-gangguan-sinyal?page $=$ all (accessed 15 January 2019).

\section{Light Rail \\ Train project in Palembang, Indonesia}


PAP

23,3

312

Landry, C. (2006), "The art of city-making”, Australian Planner, Vol. 43 No. 4, p. 47.

Liputan6 (2019), "LRT Palembang Masih Sepi Peminat", (Palembang LRT lacks of passengers), 24 February, available at: https://www.liputan6.com/regional/read/3902515/lrt-palembang-masihsepi-peminat (accessed 15 January 2019).

Lussetyowati, T. (2015), "Preservation and conservation through cultural heritage tourism: case study Musi Riverside Palembang", Procedia - Social and Behavioral Sciences, Vol. 184, pp. 401-406.

Mcclelland, J. (2015), "The future of smart cities", Raconteur, 28 June, available at: https://www. raconteur.net/digital-transformation/the-future-of-smart-cities (accessed 15 January 2019).

McGee, T.G. (1991), The Emergence of Desakota Regions in Asia: Expanding Hypothesis, The Extended Metropolis: Settlement Transition in Asia, University of Hawaii Press, Honolulu.

Media Indonesia (2019), "Pemerintah Fasilitasi Indonesia-Tiongkok Bangun Infrastruktur" (Indonesian Government facilitates China to support infrastructure projects), 16 June, available at: https://mediaindonesia.com/read/detail/241419-pemerintah-fasilitasi-indonesiationgkok-bangun-infrastruktur (accessed 15 January 2019).

Mitchell, W.J., Inouye, A.S. and Blumenthal, M.S. (2001) (Eds.), Beyond Productivity: Information Technology, Innovation, and Creativity, National Research Council, The National Academies Press, Washington, DC.

Podlaszewska, R.S.A. (2017), "The place making of destination, localization, and commoditization process in urban tourism: study case of Palembang, Indonesia”, unpublished doctoral thesis, Fakultät Architektur, Bauhaus-Universität Weimar, Weimar.

Pratama, A.B. and Imawan, A.J. (2019), "A scale for measuring perceived bureaucratic readiness for smart cities in Indonesia", Public Administration and Policy: An Asia-Pacific Journal, Vol. 22 No. 1, pp. 25-39.

Prima, L. (2014), "Cultural heritage tourism: case study of Palembang", SPACE: Journal of the Built Environment, Vol. 1 No. 2, pp. 139-150.

Saner, R. and Yiu, L. (2019), "Jamaica's development of women entrepreneurship: challenges and opportunities", Public Administration and Policy: An Asia-Pacific Journal, Vol. 22 No. 2, pp. 152-172.

Scott, J.A. (2006), "Creative cities: conceptual issues and policy questions", Journal of Urban Affairs, Vol. 28 No. 1, pp. 1-17.

Seitinger, S. (2004), "Spaces of innovation: $21^{\text {st }}$ century technopoles", unpublished master's thesis, Department of Urban Studies and Planning, Massachusetts Institute of Technology (MIT), Massachusetts.

Setkab (Cabinet Secretariat of the Republic of Indonesia) (2018), "South Sumatra LRT expected to operate next month", 24 June, available at: https://setkab.go.id/en/south-sumatra-lrt-expected-tooperate-next-month (accessed 12 August 2019).

Sripoku (2019), “Tiap 39 Menit Sekali Terjadi Kejahatan, Kapolda Sumsel Klaim Angka Kriminalitas di Sumsel Menurun" (Every 39 minutes crime happens, South Sumatra Police Chief claims crime rate in South Sumatra decreases), 1 January, available at: https://palembang.tribunnews. com/2019/01/01/tiap-39-menit-sekali-terjadi-kejahatan-kapolda-sumsel-klaim-angkakriminalitas-di-sumsel-menurun (accessed 15 January 2019).

Suara (2017), “APBN Tak cukup, Menkeu Minta Kontraktor LRT Palembang Cari Dana”, (Due to insufficient national budget, Minister of Finance suggested Palembang LRT contractors should seek for financial supporters), 25 May, available at: https:/www.suara.com/bisnis/2017/05/25/ 110555/apbn-tak-cukup-menkeu-minta-kontraktor-lrt-palembang-cari-dana (accessed 15 January 2019).

Tempo (2019), "Proyek Infrastruktur Cina di Indonesia Paling Besar se-ASEAN", (Chinese biggest infrastructural project in ASEAN is in Indonesia), 24 June, available at: https://bisnis.tempo.co/ $\mathrm{read} / 1217714 /$ proyek-infrastruktur-cina-di-indonesia-paling-besar-se-asean/full\&view $=\mathrm{ok}$ (accessed 15 January 2019).

Tsang, Y.S. (2019), "Sober minds are needed to understand what is going on in Hong Kong", Public Administration and Policy: An Asia-Pacific Journal, Vol. 22 No. 2, pp. 97-99. 
Verma, B., Snodgrass, R., Henry, B., Smith, B. and Daim, T. (2020), "Smart cities: an analysis of smart transportation management", in Tiwari, R. and Buse, S. (Eds.), Managing Innovation in a Global and Digital World: Meeting Societal Challenges and Enhancing Competitiveness, Springer Gabler, Wiesbaden.

Visitmusi2008 (2007), "Palembang city map", available at: https:/mubawisata.files.wordpress.com/ 2011/08/mappalembang.jpg (accessed 15 January 2019).

Vivanews (2018), "Palembang Jadi Kota Paling Berkembang di Indonesia", (Palembang becomes the most developing city in Indonesia), 3 May, available at: https:/www.viva.co.id/berita/nasional/ 1032783-palembang-jadi-kota-paling-berkembang-di-indonesia (accessed 15 January 2010).

Wang, S., Chan, K. and Han, K. (2019), "Impacts of the social welfare system on the employment status of low-income groups in urban China", Public Administration and Policy: An Asia-Pacific Journal, Vol. 22 No. 2, pp. 125-137.

Warta Ekonomi (2019), "Perusahaan Asal China Investasi Rp17,1 Triliun Garap Infrastruktur", (Chinese company invests IDR 17.1 trillion to work on infrastructure), 29 October, available at: https://www.wartaekonomi.co.id/read254051/perusahaan-asal-china-investasi-rp171-triliungarap-infrastruktur.html (accessed 15 January 2019).

Yin, R.K. (2013), Case Study Research: Design and Methods, Sage, Thousand Oaks, CA.

\begin{abstract}
About the author
Muhammad Akbar Hairi is $\mathrm{PhD}$ candidate of College Policy and Administration in Huazhong Science and Technology University (HUST), Wuhan, China. Prior to receiving his Master degree from Faculty of Social and Political Science at University of Indonesia, he obtained his Bachelor degree from Faculty of Social and Political Science at Universitas Gadjah Mada, Indonesia. He was a Lecturer and Head of the Government Science program, Government and Culture Department, Universitas Indo Global Mandiri, Palembang, South of Sumatera, Indonesia. Muhammad Akbar Hairi can be contacted at: akbarsyafaat307@yahoo.com
\end{abstract}

For instructions on how to order reprints of this article, please visit our website: www.emeraldgrouppublishing.com/licensing/reprints.htm Or contact us for further details: permissions@emeraldinsight.com 